\title{
Synthesis of Annulated N-Containing Heterocycles via C-H Activation
}

Key words

palladium catalysis

pyrroles

pyrazoles

C-H activation<smiles></smiles><smiles>[R]c1ccccc1I</smiles>

$\mathrm{PdCl}_{2}$ or $\mathrm{Pd}(\mathrm{OAc})_{2}(10 \mathrm{~mol} \%)$ (2-furyl $)_{3} \mathrm{P}(22 \mathrm{~mol} \%)$ $\mathrm{Cs}_{2} \mathrm{CO}_{3}$, norbornene $\mathrm{MeCN}, 90^{\circ} \mathrm{C}, 23 \mathrm{~h}$<smiles>[R7]c1cccc2c1-c1ccc([Tl])n1[Y4]C2</smiles>
10 examples, $59-91 \%$<smiles>BrCCn1cccn1</smiles><smiles>Ic1ccccc1I</smiles>
$\mathrm{Pd}(\mathrm{OAc})_{2}(10 \mathrm{~mol} \%)$ (2-furyl) $)_{3} \mathrm{P}(22 \mathrm{~mol} \%)$ $\mathrm{Cs}_{2} \mathrm{CO}_{3}$, norbornene $\mathrm{MeCN}, 90^{\circ} \mathrm{C}, 20 \mathrm{~h}$<smiles>[R]c1ccc2c(c1)-c1ccnn1CC2</smiles>
4 examples, $42-54 \%$

\section{$\mathrm{n}=1,2$
$\mathrm{R}^{1}=\mathrm{H}, \mathrm{CO}_{2} \mathrm{Et}$}

$\mathrm{R}^{2}=\mathrm{Me}, \mathrm{N}(\mathrm{Me}) \mathrm{Ts}$, OMe, Cl

$\mathrm{R}^{3}=\mathrm{H}, 3-\mathrm{CO}_{2} \mathrm{Me}, 4-\mathrm{CO}_{2} \mathrm{Me}$, 4-N(Me)Ts, 3- $\mathrm{NO}_{2}$, 3-OMe, 4-OMe

\section{$\mathrm{R}^{1}=\mathrm{Me}, \mathrm{F}, \mathrm{CF}_{3}$}

$\mathrm{R}^{2}=\mathrm{H}$ or $\mathrm{R}^{1}, \mathrm{R}^{2}=2,3-(\mathrm{CH}=\mathrm{CH})_{2}$

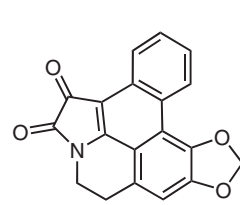

Lettowianthine

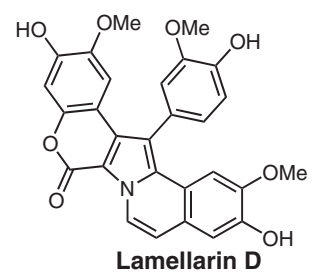

Significance: Starting with simple, readily prepared starting materials, a one-step, two-C-Cbond-forming approach to highly substituted sixand seven-membered annulated pyrroles and pyrazoles is described. The efficient palladiumcatalyzed synthesis takes advantage of a mechanistically interesting norbornene-mediated sequential aromatic alkylation/aryl-heteroaryl coupling (Catellani-type reaction) and tolerates electron-withdrawing and electron-donating groups at 2-, 3-, and 4-positions of the iodoarenes.
Comment: In comparison with previous methods which involve multi-step syntheses of such annulated heterocycles (e.g., H.-J. Knölker, S. Agarwal Tetrahedron Lett. 2005, 46, 1173-1175; W. R. Bowman et al. Tetrahedron 2005, 61, 26892696), the present one-step approach is more efficient and powerful. As an expansion of the previous similar annulation with indoles (M. Lautens et al. J. Am. Chem. Soc. 2005, 127, 13148-13149), this methodology allows rapid construction of unique tricyclic skeletons which are found in natural products and bioactive compounds, such as lettowianthine and lamellarin D.

SYNFACTS Contributors: Victor Snieckus, Yigang Zhao 